\title{
ArcheoSciences
}

Revue d'archéométrie

33 (suppl.) | 2009

Mémoire du sol, espace des hommes

\section{Geophysical study to characterize input karst water circulation in the saulges cave (Mayenne, France)}

Rémi Valois, Roger Guérin, Romain Pigeaud and Joël Rodet

\section{OpenEdition}

Journals

Electronic version

URL: https://journals.openedition.org/archeosciences/1516

DOI: 10.4000/archeosciences.1516

ISBN: 978-2-7535-1599-4

ISSN: $2104-3728$

Publisher

Presses universitaires de Rennes

\section{Printed version}

Date of publication: 30 October 2009

Number of pages: $163-166$

ISBN: 978-2-7535-0943-6

ISSN: $1960-1360$

\section{Electronic reference}

Rémi Valois, Roger Guérin, Romain Pigeaud and Joël Rodet, "Geophysical study to characterize input karst water circulation in the saulges cave (Mayenne, France)", ArcheoSciences [Online], 33 (suppl.) I 2009, Online since 30 October 2011, connection on 01 February 2022. URL: http://

journals.openedition.org/archeosciences/1516 ; DOI: https://doi.org/10.4000/archeosciences.1516 


\title{
Geophysical study to characterize input karst water circulation in the saulges cave (Mayenne, France)
}

\author{
Rémi Valois*, Roger Guérin*, Romain Pigeaud ** and Joël Rodet***
}

Key words: Karst, Geophysics, Saulges, Margot, Geology.

\section{INTRODUCTION}

The landscape around the Saulges caves is a limestone plateau cut by the valley of the river Erve. Some of the caves in the sides of this valley contain prehistoric art (Pigeaud, 2004; Pigeaud et al., 2006) and should therefore be protected from water trickling down the walls. This study is part of a program: "Occupations paléolithiques de la vallée de l'Erve" conducted by UMR 6566 for CNRS “CReAAH", coordinated by Jean-Laurent Monnier.

Geophysics could be useful in finding new caves and detecting preferential pathways (Al Fares et al., 2002; Guérin and Benderitter, 1995; Guérin et al., 2008). A frequencydomain electromagnetism instrument at low induction number (EM31) was used to map the site and to detect geological anomalies. Electrical Resistivity Tomography (ERT) gave details on a small number of anomalies.

\section{GEOPHYSICAL METHODOLOGY}

The EM31 equipment is a simple "slingram" (McNeill, 1980; Frischknecht et al., 1991) consisting of a magnetic dipole (a current loop) transmitter $\left(\mathrm{T}_{\mathrm{x}}\right)$ and a coplanar magnetic dipole receiver $\left(\mathrm{R}_{\mathrm{x}}\right)$ operating at a fixed frequency of $9.8 \mathrm{kHz}$. This instrument is used to map average variations of electrical conductivity at depths between 0 and $5.5 \mathrm{~m}$ in the DMV (Dipole Magnetic Vertical) configuration. In fact, in DMV configuration, the axes of the two magnetic loops are vertical and the sensors are more sensitive to average conductivity around $1.8 \mathrm{~m}$ below the surface.

The ERT system (Dahlin, 2001) is a multi-electrode resistivity-meter. It consists of an electrode array, control unit, data acquisition and processing unit, image reconstruction and analysis unit. The sensor of the ERT system is an electrode array with 72 metal electrodes locating equidistantly along a profile. The exciting current is injected between two electrodes order by order, and two other electrodes measure the electrical potential difference. An ERT helps determine horizontal and vertical electrical resistivity contrasts, and thus is able to provide geological information, like the level of fracturing. Different arrays and spacing have been carried out: Wenner-Schlumberger and dipole-dipole with inter-electrode distance of $2 \mathrm{~m}$ and $3 \mathrm{~m}$. The WennerSchlumberger array is recommended to detect horizontal and vertical structures, whereas the dipole-dipole is more

*UMR 7619 Sisyphe, University Pierre et Marie Curie-Paris 6, case 105, 4 place Jussieu, 75252 Paris cedex 05. (remi.valois@upmc.fr).(roger.guerin@ upmc.fr)

** USM 103 - UMR 7194, Département de Préhistoire du Muséum national d'Histoire naturelle, Institut de Paléontologie Humaine, 75013 Paris. (romain.pigeaud@wanadoo.fr)

*** UMR 6143 CNRS, Continental \& Coastal Morphodynamics, Laboratory of Geology, University of Rouen, 76821 Mont Saint Aignan. (joel.rodet@ univ-rouen. $f$ r) 
sensitive to vertical structures and has a bigger investigation depth, but a lower signal-to-noise ratio. Afterwards, the RES2DINV program uses the smoothness-constrained least-squares method inversion technique to produce a $2 \mathrm{D}$ model of the subsurface from the apparent resistivity data (Loke and Barker, 1996). So, a 2D model of resistivity is calculated to explain measures as best as possible and the criterion used to evaluate the model is the RMS (Roots Mean Square), difference between measured and calculated data.

Therefore, the aim of the survey is to detect karstic features, like sinkholes or fractured zones which could communicate with the underground network. New caves or extensions of known galleries are expected, too.

\section{Results}

The apparent conductivity maps (Fig. 1 and 2 ) were obtained using EM31 combined with a GPS.

In the case of the plateau (Fig. 1), a conductive anomaly appears at the bottom center of the EF section, corresponding to a circular anomaly (letter $\mathrm{M}, 12 \mathrm{mS} / \mathrm{m}$ vs. $5 \mathrm{mS} / \mathrm{m}$ in the neighborhood) on the EM31 map. These measurements are evidence for a big overburden. It seems to communicate with the underground network, because of the vertical anomaly in the section at coordinate $x=62 \mathrm{~m}$. However, the latter could be an artifact of the inversion processing, so this vertical structure should be interpreted with caution. Another conductive zone is observed to the left of the section, at a depth between 10 and $20 \mathrm{~m}$; it seems to be in relation with a large rectangular anomaly (letter $\mathrm{N}$ ) on the conductivity map. Further investigations are needed to confirm and interpret these structures.

In the case of the valley (Fig. 2), the middle of the CD section presents an important discontinuity in the resistivity (100 vs. $3000 \Omega \mathrm{m}$ ) and corresponds to a light anomaly on the EM31 map. Perhaps it is a cavity (full of water or sediments) on an unknown level of the karstic network, because there is evidence of vertical connections in neighboring caves (an inferior collector, under the Erve River level, was predicted by a karst study, Rodet et al., 2001). RMS values are higher than in the case of the plateau, because the dipole-dipole array has a lower signal-to-noise ratio than the WennerSchlumberger array.

The $\mathrm{AB}$ section (Fig. 2) shows a conductive zone on the right side (coordinate $\mathrm{x}=155 \mathrm{~m}$ ) and results from the EM31 show that the profile is not set in the center of the anomaly (letter $\mathrm{P}, 15 \mathrm{mS} / \mathrm{m}$ ). The results may both correspond to an old river meander.

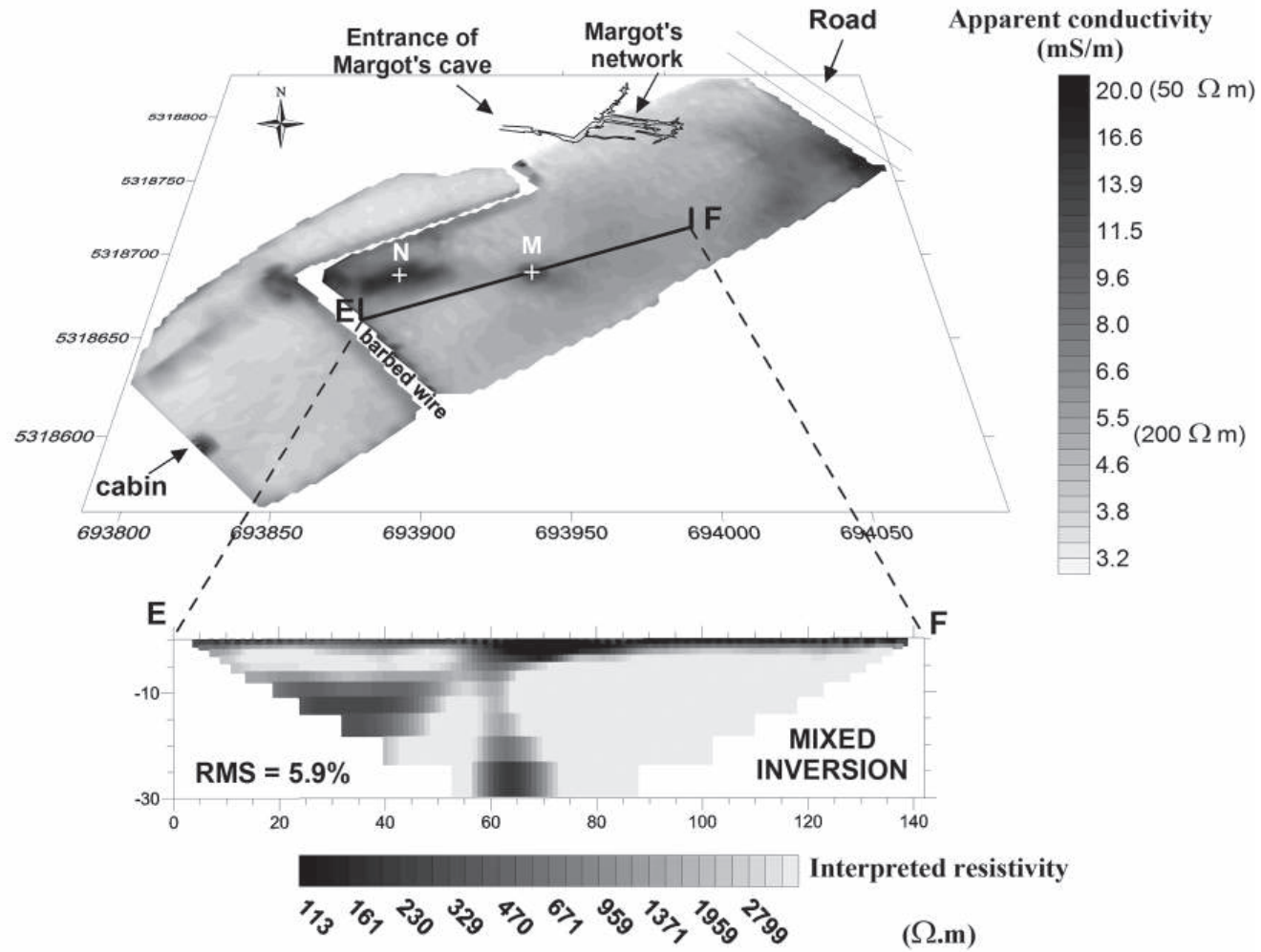

Figure 1: Section of resistivity and EM31 maps on the plateau (with a data grid around $5 \mathrm{mx} 1 \mathrm{~m}$ ). The section is a combined inversion of the WennerSchlumberger and dipoledipole arrays. A map of the known underground network was plotted (around $15 \mathrm{~m}$ below the surface) 
Figure 2: Sections of resistivity and EM31 maps in the valley (with a data grid around $5 \mathrm{mx} 1 \mathrm{~m}$ ). The river flows at the center of the map from east to west.

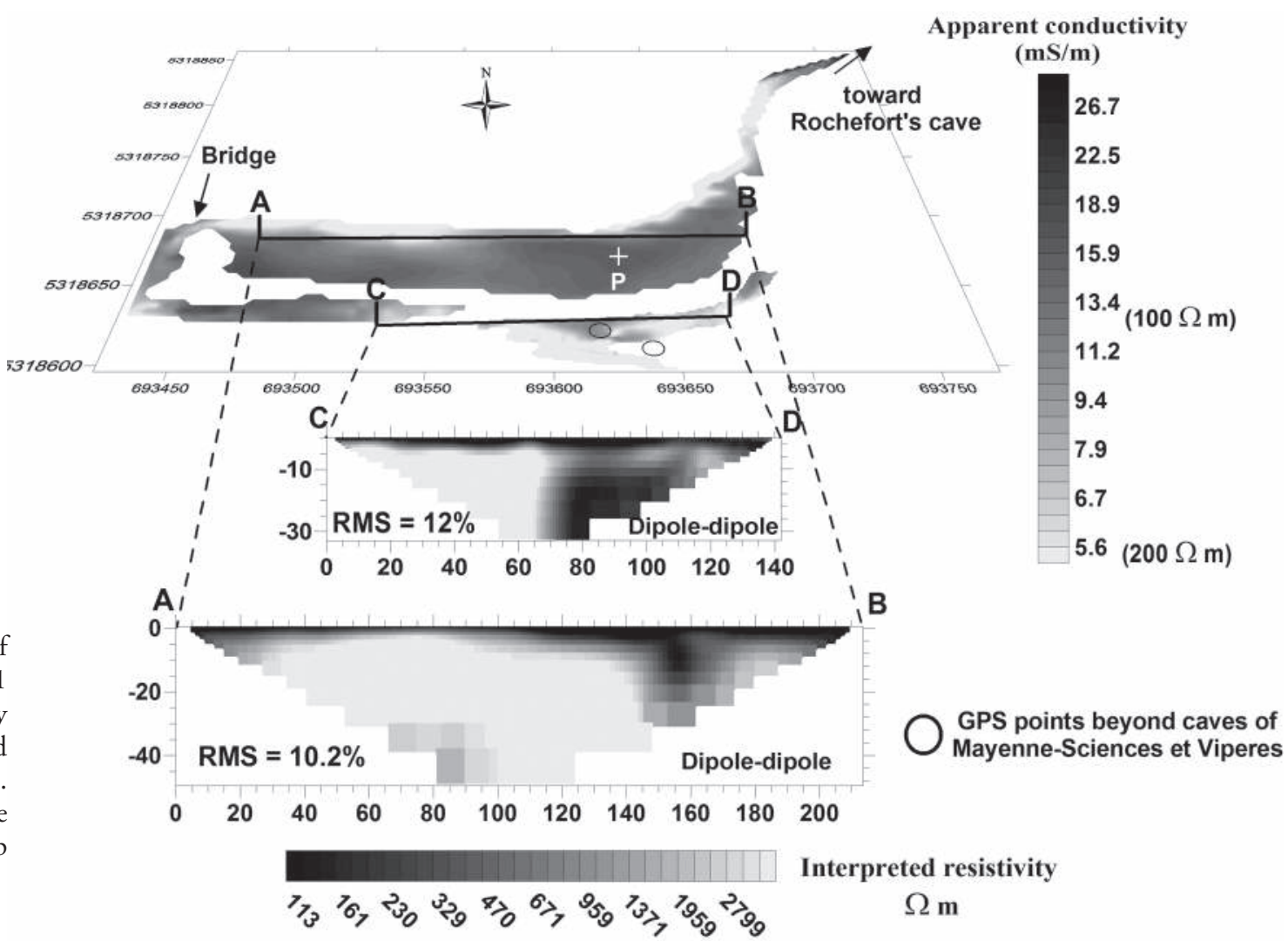

\section{Conclusion}

Some karstic structures may have been detected, but more geophysical investigations and excavation are needed to confirm these results. The survey zone has to be extended to detect other anomalies and a possible preferential direction of the fractured rocks. Connections between superficial structures and cavities have to be performed, too.

\section{References}

Al-Fares, W., Bakalowicz, M., Guerin, R. and Dukhan, M., 2002. Analysis of the karst aquifer structure of the Lamalou area (Hérault, France) with ground penetrating radar. Journal of Applied Geophysics, 51: 97-106.

Dahlin, T., 2001. The development of electrical imaging techniques. Computers and Geosciences, 27: 1019-1029.

Frischinecht, F.C., Labson, V. F., Spies, B. R. and Anderson, W. L., 1991. Profiling methods using small sources. In Nabighian M.N. (dir.). Electromagnetic methods in applied geophysics 2: Applications, chapter 3, SEG Publ., 105-270.
Guerin, R., Benderitter, Y., 1995. Shallow karst exploration using MT-VLF and DC resistivity methods. Geophysical Prospecting, 43: 635-653.

Guerin, R., Baltassat, J.-M., Boucher, M., Chalikakis, K., Galibert, P.-Y., Girard, J.-F., Plagnes, V. and Valois, R., 2008. Geophysical characterisation of karstic networks - Application to the Ouysse system (Poumeyssen, France). Comptes Rendus Geoscience, submitted.

LOKE, M. H. and BARKER, R. D., 1996. Rapid least-square inversion of apparent resistivity pseudo-sections by a quasi-newton method. Geophysical Prospecting, 44: 131-152.

Mc NeILl, J. D., 1980. Electrical terrain conductivity measurement at low induction numbers, Technical Notes TN-6, Geonics Limited.

Pigeaud, R. (aVec la collaboration de M. Bouchard et d'E. LAVAL), 2004. La grotte ornée Mayenne-Sciences (Thorignéen-Charnie, Mayenne) : un exemple d'art pariétal d'époque gravettienne en France septentrionale. Gallia Préhistoire, 46 : 1-154.

Pigeaud, R., Rodet, J., Devièse, T., Dufayet, C., TrelohanChauve, E., Betton, J.-P. and Bonic, P., 2006. Palaeolithic cave art in West France: an exceptional discovery: the Margot 
Cave (Mayenne), Antiquity, 80 (309), [http://antiquity.ac.uk/ ProjGall/pigeaud/index.html].

Rodet, J., Renault, G. and Bonic, P., 2001. Contexte karstologique de la grotte "Mayenne-Sciences" (Thorigné-en-Charnie, Mayenne) - état au 30 novembre 2001. In Pigeaud, R. (dir.).
Les occupations paléolithiques de la vallée de l'Erve, programme UMR 6566, UMR 6569 et MNHN, "Étude des représentations de la grotte Mayenne-Sciences Thorigné en Charnie, Mayenne", 44-50. 